\title{
BIBIIO \\ COUNS
}

Biblio Couns : Jurnal Kajian Konseling dan Pendidikan

Vol. 1, No. 3, November 2018, hlm. 89-96

Tersedia Online di jurnal.umsu.ac.id/index.php/biblio

ISSN 2620-3103 (online)

https://doi.org/10.30596/bibliocouns.v1i3.2245

\section{Kontribusi Konsep Diri Siswa dan Keterlibatan Orangtua terhadap Pemilihan Sekolah Lanjutan di SMP Palopo}

\author{
Aswidy Wijaya Cipta ${ }^{1}$, Ratna Wulandari ${ }^{2}$ \\ Guidance and Counseling Study Program, STKIP Muhammadiyah Palopo, Indonesia. \\ Correspondence: JI. Jend. Sudirman KM. 3, Binturu, Wara Selatan, Kota Palopo. \\ E-mail: aswidywijayacipta@stkipmpalopo.ac.id/08114414604
}

\begin{tabular}{l}
\hline Article Info \\
\hline History of Article \\
Accepted Oktober 2018 \\
Approved Oktober 2018 \\
Published November 2018 \\
\hline Key Word \\
\hline Parental; \\
SMPN 4 Palopo.
\end{tabular}

Article Info

History of Article

2018

Approved Oktober 2018

MPN 4 Palopo.

\begin{abstract}
Each year students will look for a suitable school before graduation. Problems arise when there are a lot of options that provide diverse schools offer to prospective students. Contributions of students self concept and parents involvement supposed to influence in the selection of secondary schools. This study aimed to describe:1) self-concept students of SMPN 4 Palopo, 2) parents involvement of SMPN 4 Palopo, 3) students secondary school selection, 4) the contribution students self-concept against secondary school selection, 5) contribution parental involvement against secondary school selection, 6) the contribution of students self-concept and parental involvement against secondary school selection. This corelational descriptive research applied quantitative method. The data obtained were analyzed using descriptive statistic, simple regression and multiple regression. The implication of this research may useful to design career guidance programs.
\end{abstract}

\section{Citation Info.}

Cipta, A. W., Wulandari, R. (2018, November). Kontribusi Konsep Diri Siswa Dan Keterlibatan Orangtua Terhadap Pemilihan Sekolah Lanjutan Di Smpn 4 Palopo. In Biblio Couns: Jurnal Kajian Konseling dan Pendidikan, 1(1), 89-96. 


\section{PENDAHULUAN}

Sebagai siswa yang sedang mengikuti proses pendidikan di jenjang Sekolah Menengah Pertama (SMP) sudah sewajarnya bila siswa tersebut memiliki berbagai macam keinginan dan cita-cita setelah lulus. Mereka dihadapkan pada berbagai alternatif pilihan yang perlu dilakukan untuk mengantisipasi program yang harus ditempuh selanjutnya setelah menyelesaikan pendidikan. Setiap tahun, siswa akan mencari sekolah lanjutan yang cocok untuk dirinya. Persoalan muncul ketika terdapat banyak pilihan sekolah yang memberikan beragam tawaran kepada calon siswanya. Hal inilah yang membuat siswa SMP mengalami kesulitan dalam menentukan pilihan sekolah yang tepat. Dalam kondisi yang demikian ini kemampuan siswa dalam proses pengambilan keputusan sangat berperan, artinya pihak luar hanya sebatas memberikan bimbingan dan pengarahan, sedangkan pengambilan keputusan sepenuhnya berada pada siswa itu sendiri setelah memperhatikan dan mempertimbangkan masukan dari pihak lain. Kemampuan untuk memahami yang sesungguhnya tentang diri sendiri merupakan salah satu faktor yang penting dalam menghadapi berbagai aktivitas hidup. Pemahaman diri dalam kelanjutan pendidikan sangat penting dipahami oleh masing-masing siswa, karena merupakan penentu keberhasilan masa depan mereka. Faktor lain yang dapat mempengaruhi siswa SMP untuk memilih sekolah lanjutan adalah faktor lingkungan para siswa SMP dari mulai lingkungan keluarga, dimana ketika akan memilih biasanya sekolah pilihan dari anggota keluarga sebelumnya. Hal tersebut disebabkan sekolah yang telah dipilih sebelumnya menjadi tidak asing lagi dalam lingkungan keluarga. Dalam memilih arah pilihan karier atau yang dimaksud dalam penelitian ini adalah memilih sekolah lanjutan, individu bisa dikatakan berada dalam kondisi yang dilematis karena hal tersebut terkait dengan kemampuan maupun minat dalam memilih masih kurang.

Pada usia SMP, siswa cenderung membuat keputusan karier bukan pada pertimbangan yang matang (Lugianto, dkk., 2011; Ginzberg, dkk., dalam Middleton \& Loughead, 1993). Sehubungan dengan eksplorasi karier, dalam hal ini pemilihan sekolah lanjutan siswa SMP dipengaruhi oleh dua faktor, yaitu faktor internal dan faktor eksternal. Faktor internal yang dimaksud di sini adalah konsep diri siswa, sedangkan faktor eksternal yang berpengaruh terhadap pemilihan sekolah lanjutan siswa adalah dukungan serta keterlibatan orangtua dalam karier anaknya (Greenhaus \& Callanan dalam Purwanta, 2012). Konsep diri sebagai faktor internal dalam pemilihan sekolah lanjutan sangat diperlukan karena dengan siswa memahami dirinya diharapkan siswa dapat merencanakan langkahlangkah yang akan ditempuhnya ketika tamat dari SMP. Burgoyne (dalam Betz, 1994) mengemukakan konsep diri ideal berperan penting dalam memilih pekerjaan. Konsep diri terdiri dari bagaimana melihat diri kita sendiri sebagai pribadi, juga bagaimana merasa tentang diri sendiri, serta menginginkan diri sendiri menjadi manusia sebagaimana yang kita harapkan. Sedangkan, faktor eksternal yang mempengaruhi pemilihan sekolah lanjutan adalah adanya keterlibatan orangtua dalam proses tersebut. Fenomena di lapangan menunjukkan konsep diri dan keluarga merupakan aspek yang menentukan pemilihan sekolah lanjutan siswa. Hal tersebut terungkap dari hasil observasi peneliti di SMPN 04 Palopo pada bulan November 2017. Sebagian besar siswa kelas IX mengungkapkan bahwa untuk masalah pemilihan sekolah lanjutan, siswa menyerahkan kepada orangtua. Hal tersebut akibat kemampuan siswa mengelola diri sendiri, memahami orang lain dan lingkungan serta berhubungan baik dengan orang lain dan lingkungannya masih belum bagus (Clark dalam Wahab, 2005). Fenomena tersebut menunjukkan bahwa konsep diri siswa serta keterlibatan orangtua memiliki peranan terhadap pemilihan sekolah lanjutan. Namun, bagaimana besar kecilnya kontribusi antara faktor-faktor tersebut, maka perlu 
dilakukan penelitian. Hasil dari penelitian inilah yang akan dijadikan acuan dalam penyusunan program BK. Hal inilah yang menjadi dasar penelitian ini dilakukan, karena belum adanya temuan penelitian yang menunjukkan seberapa besar kontribusi konsep diri dan keterlibatan orangtua terhadap pemilihan sekolah lanjutan siswa SMPN 04 Palopo. Tujuan penelitian ini dirumuskan sebagai berikut: (1) mendeskripsikan gambaran konsep diri siswa SMPN 04 Palopo, (2) mendeskripsikan gambaran keterlibatan orangtua siswa SMPN 04 Palopo, (3) mendeskripsikan gambaran pemilihan sekolah lanjutan siswa di SMPN 04 Palopo, (4) menguji kontribusi konsep diri siswa terhadap pemilihan sekolah lanjutan di SMPN 04 Palopo, (5) menguji kontribusi keterlibatan orangtua siswa terhadap pemilihan sekolah lanjutan di SMPN 04 Palopo, (6) menguji kontribusi konsep diri siswa dan keterlibatan orangtua terhadap pemilihan sekolah lanjutan di SMPN 04 Palopo.

\section{METODE}

Penelitian ini menggunakan metode kuantitatif jenis deskriptif korelasional. Populasi penelitian adalah siswa kelas IX SMPN 04 Palopo yang berjumlah 210 orang, sampel berjumlah 140 orang, yang dipilih dengan teknik proportional stratified random sampling. Instrumen yang digunakan adalah skala model likert. Data dianalisis dengan statistik deskriptif, regresi sederhana dan ganda. Analisis data dibantu dengan menggunakan program SPSS versi 23.

\section{HASIL}

\section{Deskripsi Data}

1. Konsep Diri Siswa (X1)

Deskripsi data konsep diri siswa yang berjumlah 136 responden dapat dilihat pada tabel berikut.

Tabel 1. Skor Konsep Diri Siswa SMPN 04 Palopo

\begin{tabular}{|c|l|c|c|}
\hline \multirow{2}{*}{ No } & \multicolumn{2}{|c|}{ Sub Variabel } & \multicolumn{2}{|c|}{ Skor } \\
\cline { 3 - 4 } & & $\begin{array}{c}\text { Rata-rata } \\
\text { Capaian (\%) }\end{array}$ & Ket \\
\hline 1 & Perceptual & 77 & $\mathrm{~T}$ \\
\hline 2 & Conceptual & 64.2 & $\mathrm{~S}$ \\
\hline 3 & Attitudinal & 64 & $\mathrm{~S}$ \\
\hline \multicolumn{2}{|c|}{ Keseluruhan Konsep Diri Siswa } & 68 & $\mathrm{~T}$ \\
\hline
\end{tabular}

Berdasarkan tabel di atas dapat diketahui keseluruhan skor capaian rata-rata sebesar $68 \%$ dan diartikan bahwa secara rata-rata tingkat konsep diri siswa tinggi. Lebih rinci pada sub variabel perceptual, rata-rata capaiannya $77 \%$. Dengan demikian secara ratarata tingkat konsep diri siswa pada sub variabel perceptual tinggi. Selanjutnya, sub variabel conceptual rata-rata capaiannya $64.2 \%$. Dengan demikian secara rata-rata tingkat konsep diri siswa pada sub variabel conceptual berada pada kategori sedang. Terakhir pada sub variabel attitudinal rata-rata capaiannya 64\%. Dengan demikian, secara rata-rata tingkat konsep diri siswa pada sub variabel attitudinal berada pada kategori sedang. 


\section{Keterlibatan Orangtua (X2)}

Deskripsi data keterlibatan orangtua berdasarkan persepsi siswa yang berjumlah 136 responden dapat dilihat pada Tabel 2.

Tabel 2. Skor Keterlibatan Orangtua

\begin{tabular}{|c|l|c|c|}
\hline \multirow{2}{*}{ No } & \multicolumn{2}{|c|}{ Sub Variabel } & \multicolumn{2}{c|}{ Skor } \\
\cline { 3 - 4 } & & $\begin{array}{c}\text { Rata-rata } \\
\text { Capaian (\%) }\end{array}$ & Ket \\
\hline 1 & Pendidik & 76.2 & $\mathrm{~T}$ \\
\hline 2 & Motivator & 66.5 & $\mathrm{~S}$ \\
\hline 3 & Fasilitator & 60.3 & $\mathrm{~S}$ \\
\hline 4 & Suporter & 62.7 & $\mathrm{~S}$ \\
\hline 5 & Teladan & 67.7 & $\mathrm{~S}$ \\
\hline \multicolumn{2}{|c|}{ Keseluruhan Keterlibatan Orangtua } & 68 & $\mathrm{~T}$ \\
\hline
\end{tabular}

Berdasarkan tabel di atas, dapat dilihat rata- rata capaian yang diperoleh siswa sebesar $68 \%$. Jadi, secara rata-rata tingkat keterlibatan orangtua berada pada kategori tinggi. Lebih lanjut, pada sub variabel pendidik dengan capaian $76.2 \%$, secara rata-rata tingkat keterlibatan orangtua pada sub variabel pendidik berada pada kategori tinggi. Kemudian, pada sub variabel motivator rata- rata capaian yang diperoleh siswa yaitu $66.5 \%$. Dengan demikian, secara rata-rata tingkat keterlibatan orangtua pada sub variabel motivator berada pada kategori sedang. Sub variabel fasilitator rata-rata skor yaitu $60.3 \%$. Secara rata-rata tingkat keterlibatan orangtua pada sub variabel fasilitator berada pada kategori sedang. Lebih lanjut, pada sub variabel suporter dengan rata-rata capaian sebesar $62.7 \%$. Dengan demikian, secara rata-rata tingkat keterlibatan orangtua siswa pada sub variabel pendidik berada pada kategori sedang. Selanjutnya, pada sub variabel model/teladan rata-rata capaian yang diperoleh siswa yaitu $67.7 \%$. Dengan demikian, secara rata-rata tingkat keterlibatan orangtua siswa pada sub variabel motivator berada pada kategori sedang.

3. Pemilihan Sekolah Lanjutan (Y)

Deskripsi data pemilihan sekolah lanjutan yang berjumlah 136 responden dapat dilihat pada Tabel 3.

Tabel 3. Skor Pemilihan Sekolah Lanjutan

\begin{tabular}{|c|l|c|c|}
\hline \multirow{2}{*}{ No } & \multicolumn{1}{|c|}{ Sub variabel } & \multicolumn{2}{|c|}{ Skor } \\
\cline { 3 - 4 } & $\begin{array}{c}\text { Rata-rata } \\
\text { Capaian (\%) }\end{array}$ & Ket \\
\hline 1 & $\begin{array}{l}\text { Penyesuaian bakat dan minat anak } \\
2\end{array}$ & $\begin{array}{l}\text { Penyesuaian kemampuan fisik, } \\
\text { akademis dan sosial ekonomi } \\
\text { Anak }\end{array}$ & 75.9 \\
\hline 3 & $\begin{array}{l}\text { Penyesuaian keadaan } \\
\text { lanjutan yang akan dipilih }\end{array}$ & $\mathrm{T}$ \\
\hline 4 & $\begin{array}{l}\text { Melihat peluang yang tersedia pada } \\
\text { sekolah lanjutan }\end{array}$ & 81.5 & $\mathrm{~T}$ \\
\hline 5 & $\begin{array}{l}\text { Harapan terhadap prospek masa } \\
\text { depan setelah lulus }\end{array}$ & 83.3 & $\mathrm{~T}$ \\
\hline Keseluruhan Pemilihan Sekolah Lanjutan & 80.7 & $\mathrm{~T}$ \\
\hline
\end{tabular}

Berdasarkan Tabel 3, dapat diketahui bahwa secara keseluruhan rata-rata capaian yang diperoleh siswa $80.7 \%$. Dengan demikian, secara rata-rata kualitas pemilihan sekolah lanjutan siswa berada pada kategori tinggi. Indikator penyesuaian bakat dan minat anak rata-rata skornya yaitu $80.6 \%$. Dengan demikian, secara rata-rata tingkat 
pemilihan sekolah lanjutan siswa pada indikator penyesuaian bakat dan minat berada pada kategori tinggi. Selanjutnya, pada indikator penyesuaian kemampuan fisik, akademis dan sosial ekonomi anak rata-rata skornya yaitu $75.9 \%$. Dengan demikian, secara rata-rata tingkat pemilihan sekolah lanjutan siswa pada indikator penyesuaian kemampuan fisik, akademis, dan sosial ekonomi anak berada pada kategori tinggi. Kemudian, pada indikator penyesuaian keadaan sekolah lanjutan rata-rata skornya yaitu $81.5 \%$. Dengan demikian, secara rata-rata tingkat keterlibatan orangtua pada indikator fasilitator berada pada kategori tinggi. Lebih lanjut, pada indikator melihat peluang yang tersedia pada sekolah lanjutan rata-rata skornya yaitu $82.3 \%$. Dengan demikian, secara rata-rata tingkat keterlibatan orangtua siswa pada indikator pendidik berada pada kategori tinggi. Selanjutnya, pada indikator harapan terhadap prospek masa depan setelah lulus rata- rata skor yang diperoleh siswa yaitu 83.3\%. Dengan demikian, secara rata-rata tingkat keterlibatan orangtua siswa pada indikator motivator berada pada kategori tinggi.

\section{Pengujian Persyaratan Analisis}

Pengujian hipotesis dilakukan dengan analisis regresi. Persyaratan yang harus dipenuhi untuk analisis regresi adalah sebagai berikut ini.

1. Uji Normalitas

Uji normalitas dilakukan dengan metode Kolmogorov-Smirnov dengan tujuan untuk mengetahui apakah data berasal dari populasi normal.

Tabel 4. Hasil Uji Normalitas

\begin{tabular}{|l|c|c|}
\hline \multirow{2}{*}{\multicolumn{1}{|c|}{ Variabel }} & \multicolumn{2}{c|}{ Kolmogorov- Smirnov } \\
\cline { 2 - 3 } & Df & Sig. \\
\hline Konsep diri siswa & 136 & .200 \\
\hline Keterlibatan orangtua & 136 & .095 \\
\hline Pemilihan sekolah lanjutan & 136 & .200 \\
\hline
\end{tabular}

Tabel 4 menunjukkan bahwa konsep diri siswa dan keterlibatan terhadap pemilihan sekolah lanjutan memiliki P-value yang lebih besar dari 0.05. Dengan demikian, dapat disimpulkan bahwa data berasal dari populasi yang distribusi normal. Hal ini menunjukkan bahwa salah satu syarat untuk analisis regresi sudah terpenuhi.

\section{Uji Linieritas}

Uji linieritas dilakukan dengan memanfaatkan fungsi compare means pada program SPSS versi 23. Hasil uji linieritas kontribusi variabel konsep diri siswa terhadap pemilihan sekolah lanjutan diperoleh nilai $F=116.349$ dengan $p=0.000(p<0.05)$. Hasil tersebut menunjukkan bahwa variabel konsep diri siswa terhadap pemilihan sekolah lanjutan bersifat linear atau mengikuti garis lurus. Uji linieritas keterlibatan orangtua terhadap pemilihan sekolah lanjutan diperoleh hasil $F=137.101$ dengan $p=0.000(p<0.05)$. Hasil tersebut menunjukkan bahwa variabel keterlibatan orangtua bersifat linear atau mengikuti garis lurus terhadap variabel pemilihan sekolah lanjutan.

\section{Uji Multikolinieritas}

Melihat kemungkinan terjadinya multikolinieritas digunakan bantuan SPSS versi 23. Apabila nilai Variance Inflation Factor (VIF) 10 atau lebih menjadi aturan praktis untuk menyimpulkan VIF terlalu besar, sehingga disimpulkan terjadi multikolinieritas. Berdasarkan hasil analisis data, dapat diketahui bahwa tidak terjadi multikolinieritas antara konsep diri siswa dan keterlibatan orangtua. 
Kontribusi Konsep Diri Siswa dan Keterlibatan Orangtua terhadap Pemilihan Sekolah Lanjutan

a. Kontribusi Konsep Diri Siswa terhadap Pemilihan Sekolah Lanjutan Siswa

Hasil analisis kontribusi konsep diri siswa terhadap pemilihan sekolah lanjutan diperoleh nilai $R$ sebesar 0.666 dengan nilai $R$ Square sebesar 0.443 . Hal ini memperlihatkan $44.4 \%$ besarnya kontribusi konsep diri siswa terhadap pemilihan sekolah lanjutan siswa.

b. Kontribusi Keterlibatan Orangtua terhadap Pemilihan Sekolah Lanjutan

Hasil analisis kontribusi keterlibatan orangtua terhadap pemilihan sekolah lanjutan diperoleh nilai $\mathrm{R}$ sebesar 0.715 menunjukkan koefisien regresi keterlibatan orangtua terhadap pemilihan sekolah lanjutan siswa. Nilai R Square sebesar 0.511, yang menunjukkan bahwa besarnya kontribusi sebesar $51.1 \%$ pada pemilihan sekolah lanjutan siswa.

\section{KESIMPULAN}

Berdasarkan temuan dan pembahasan hasil penelitian dapat disimpulkan.

1) Secara rata-rata tingkat konsep diri siswa berada pada kategori tinggi, keterlibatan orangtua siswa berada pada kategori tinggi, dan kualitas pemilihan sekolah lanjutan siswa SMPN 04 Palopo tergolong pada kategori tinggi.

2) Konsep diri siswa memberikan kontribusi terhadap pemilihan sekolah lanjutan siswa sebesar $44.3 \%(R=0.666, R 2=0.443$, dan signifikansi 0.000$)$. Artinya, sebanyak $44.3 \%$ konsep diri siswa memberikan sumbangan terhadap pemilihan sekolah lanjutan.

3) Terdapat kontribusi keterlibatan orangtua terhadap pemilihan sekolah lanjutan siswa sebesar $51.1 \%(R=0.715, R 2=0.511$, dan signifikansi 0.000$)$. Artinya, sebanyak $51.1 \%$ keterlibatan orangtua memberikan sumbangan terhadap pemilihan sekolah lanjutan.

4) Secara bersama-sama terdapat kontribusi konsep diri siswa dan keterlibatan orangtua terhadap pemilihan sekolah lanjutan siswa. Hasil penelitian menunjukkan bahwa koofisien regresi $(R)$ sebesar 0.736 dan (R2) sebesar 0.542 , atau $54.2 \%$. Artinya, tinggi rendahnya pemilihan sekolah lanjutan tidak hanya dipengaruhi oleh satu variabel saja (konsep diri siswa atau keterlibatan orangtua), namun dipengaruhi secara bersama-sama oleh konsep diri siswa dan keterlibatan orangtua. Dapat dikatakan bahwa semakin tinggi konsep diri siswa dan semakin positif keterlibatan orangtua, maka semakin tinggi pemilihan sekolah lanjutan. Hal ini berarti variabel konsep diri siswa dan keterlibatan orangtua akan lebih efektif jika dikombinasikan secara bersama-sama sebagai prediktor untuk meningkatkan pemilihan sekolah lanjutan daripada hanya satu variabel saja. Selanjutnya, secara sendiri-sendiri maka keterlibatan orangtua paling efektif memberikan sumbangan terhadap pemilihan sekolah lanjutan diikuti oleh konsep diri siswa.

Implikasi

Hasil penelitian ini menunjukkan bahwa terdapat kontribusi yang signifikan antara konsep diri siswa dan keterlibatan orangtua terhadap pemilihan sekolah lanjutan. Sehingga memberikan implikasi sebagai berikut:

1) Memantapkan Konsep diri siswa

Guru BK atau Konselor dapat mengembangkan konsep diri siswa melalui layanan BK Karier. Karena melalui layanan ini, siswa akan mendapatkan tambahan informasi karier ataupun konseling secara perorangan jika menghadapi kesulitan dalam memilih sekolah lanjutan. 
2) Mengubah Keterlibatan Orangtua Terhadap Pemilihan Sekolah Lanjutan Agar Lebih Memahami Kebutuhan Anak

Guru BK atau Konselor diharapkan dapat mengubah persepsi orangtua agar tidak memaksakan kehendaknya kepada anak. Orangtua harus memahami apa yang sebenarnya dibutuhkan anak dalam memilihi sekolah lanjutan. Karena orangtua yang memaksakan kehendaknya pada anak, akan mengakibatkan ketidaksesuaian karier yang akan dijalaninya kelak.

Saran

Berdasarkan hasil penelitian, terdapat kontribusi yang positif dan signifikan antara konsep diri siswa dan keterlibatan orangtua terhadap pemilihan sekolah lanjutan siswa. Berdasarkan hal tersebut, maka peneliti memberikan saran sebagai berikut.

1) Hasil ini kiranya dapat dijadikan sebagai bahan masukan bagi guru BK untuk dapat membuat kegiatan pertemuan dengan orangtua siswa untuk membahas pentingnya keterlibatan dari orangtua untuk meningkatkan pemilihan sekolah lanjutan siswa, selanjutnya guru BK SMPN 04 Palopo agar dapat meningkatkan konsep diri siswa dengan memberikan pelayanan yang lebih terprogram, baik layanan informasi tentang bagaimana membentuk konsep diri siswa, atau juga konseling perorangan mengenai permasalahan konsep diri siswa.

2) Bagi kepala SMPN 04 Palopo, disarankan untuk dapat menambah jam khusus untuk setiap kelas kepada guru BK sehingga guru BK dapat melaksanakan layanannya dengan baik, di samping itu disarankan juga untuk dapat mengadakan pertemuan kepada seluruh orangtua siswa membahas pentingnya keterlibatan dari orangtua untuk dapat memantapkan pemilihan sekolah lanjutan siswa.

3) Kepada orangtua siswa, disarankan untuk mengikuti program yang dilakukan sekolah seperti mengikuti dan berpartisipasi aktif pada kegiatan pertemuan orangtua ke sekolah dalam rangka meningkatkan konsep diri siswa melalui keterlibatan orangtua. 


\section{REFERENSI}

Betz, N. E. 1994. Self-Concept Theory in Career Development and Counseling. Journal of Career Development Quarterly, 43(1): 32-44.

Hadiati, R. M. 2013. "Perbedaan Minat Belajar dan Prestasi Belajar Siswa Terhadap Pemilihan Sekolah Lanjutan Atas di SMP Negeri 1 Sambirejo Tahun Pelajaran 2013/2014". Makalah tidak diterbitkan. Solo: Program Studi Sosiologi Antropologi Pendidikan IPS Fakultas Keguruan dan IImu Pendidikan Universitas Sebelas Maret Surakarta.

Hurlock, E. B. 1978. Perkembangan Anak, Jilid 2. Terjemahan oleh Meitasari Tjandrasa. 2004. Jakarta: Erlangga.

Lugianto, T., Ranto, M.T. \& Rohman, N. 2011. "Hubungan Persepsi Siswa dan Peran Bimbingan Konseling dengan Minat Memasuki SMKN 2 Surakarta Tahun Pelajaran 2011/2012". Tesis tidak diterbitkan. Surakarta: FKIP UNS.

Maryati, S. 2009. "Faktor-faktor yang Mempengaruhi Preferensi Masyarakat dalam Memilih Sekolah Menengah Kejuruan Negeri (SMKN) di Kota Semarang". Tesis tidak diterbitkan. Semarang: Program Pasca Sarjana Magister Teknik Pembangunan Wilayah dan Kota Universitas Diponegoro.

Maulida, S. R \& Dhania, D. R. 2012. "Hubungan antara Kepercayaan Diri dan Dukungan Orangtua dengan Motivasi Berwirausaha pada Siswa SMK". (Online) Vol. 11, No. 2 (http://ejournal.undip.ac.id/index.php/psikologi/article/view/6630, diakses 02 September 2017).

Munandir. 1996. Program Bimbingan Karier di Sekolah. Jakarta: Depdikbud.

Program Pascasarjana UNP. 2014. Panduan Penulisan Tesis Program Magister (S2). Edisi Revisi. Padang: Program Pascasarjana UNP.

Purnomo, C. 2014. Meningkatkan Pemahaman Studi Lanjut melalui Metode Debat Aktif dalam Layanan Bimbingan Kelompok. Jurnal Pendidikan Penabur, 22(14): 1-11.

Purwanta, E. 2012. Dukungan Orangtua dalam Karier Terhadap Perilaku Eksplorasi Karier Siswa SLTP. TEKNODIKA, 10(02): 127-140.

Slameto. 2010. Belajar dan Faktor-faktor yang Mempengaruhi. Jakarta: Rineka Cipta.

Trisnawarman, D. \& Livereja, M. 2006. "Aplikasi Sistem Pendukung Keputusan Pemilihan Sekolah". Makalah disajikan dalam Seminar Nasional Aplikasi Teknologi Informasi 2006 (SNATI 2006).

Wahab, R. 2005. "Peranan Orangtua dan Pendidik dalam Mengoptimalkan Potensi Anak Berbakat Akademik". Makalah disajikan dalam Seminar Keberbakatan, Dewan Eksekutif Mahasiswa Psikologi Universitas Diponegoro, Semarang, 28 Mei.

Walgito, B. 2005. Bimbingan dan Konseling(Studi \& Karir). Yogyakarta: Andi. 